\title{
A TÁRSADALMI INNOVÁCIÓ ÉS PÉNZÜGYI ALAPJAI, MINT SAJÁTOS (SZUPRANACIONÁLIS) JOGI TÁRGY BÜNTETŐJOGI VÉDELME AZ EURÓPAI UNIÓBAN ÉS MAGYARORSZÁGON
}

\author{
Udvarhelyi Bence \\ egyetemi tanársegéd, Miskolci Egyetem, Európai és Nemzetközi Jogi Intézet, \\ Polgári Eljárásjogi és Nemzetközi Jogi Tanszék \\ 3515 Miskolc, Miskolc-Egyetemváros, e-mail: jogbence@uni-miskolc.hu
}

\begin{abstract}
Absztrakt
A kutatás alapvető célja a társadalmi innováció pénzügyi alapjai büntetőjogi védelmének elemzése, különös tekintettel az Európai Unió pénzügyi érdekei védelmének kérdésére. A hazai és az uniós költségvetést sértő deliktumok ugyanis közvetett módon az innováció sérelmével vagy veszélyeztetésével is járhatnak, igy a magyar és az uniós jogalkotónak is elemi érdeke fellépni a pénzügyi érdekeit sértö büncselekményekkel szemben.
\end{abstract}

Kulcsszavak: társadalmi innováció, szupranacionális jogi tárgy, Európai Unió pénzügyi érdekeinek védelme, Európai Ügyészség, költségvetési csalás

\begin{abstract}
The basic aim of the research is to analyse the criminal law protection of the financial basis of social innovation, in particular the issue of the protection of the financial interests of the European Union. Criminal offences against the domestic and EU budgets can indirectly harm or endanger innovation as well, therefore it is a primary interest of the Hungarian and the EU legislators to combat against crimes affecting their financial interests.
\end{abstract}

Keywords: social innovation, supranational legal interest, protection of the financial interests of the European Union, European Public Prosecutor's Office, budget fraud

\section{Bevezető gondolatok}

A magyar büntetőjogi dogmatika jogi tárgynak nevezi azokat a védett és védendő értékeket, érdekeket, amelyeket a büncselekmények sértenek vagy veszélyeztetnek. Ha részletesen górcső alá vesszük a hatályos magyar Büntető Törvénykönyvet ${ }^{1}$, egyetlen olyan fejezetet sem találhatunk, amely expressis verbis a társadalmi innováció elleni deliktumokat sorolná fel. Ennek ellenére nem mondhatjuk azt, hogy a magyar büntetöjog ne részesítené védelemben a társadalmi innovációt, hiszen a Btk. számos olyan bủncselekményt tartalmaz, amelyek közvetlenül vagy közvetve ezt az össztársadalmi érdeket is sértik vagy veszélyeztetik. Ilyen deliktum-kategóriák lehetnek például a szellemi tulajdonjog elleni büncselekmények (különösen a bitorlás, a szerzői vagy szerzői joghoz kapcsolódó jogok megsértése és az iparjogvédelmi jogok megsértése), a vagyon elleni büncselekmények (például a lopás, a sikkasztás, a csalás, a gazdasági csalás, az információs rendszer felhasználásával elkövetett csalás, a hủtlen kezelés vagy a hanyag kezelés), egyes gazdálkodás rendjét sértö büncselekmények (például a számvitel rendjének megsértése, a bennfentes kereskedelem, a tiltott piacbefolyásolás vagy a gazdasági titok megsér-

\footnotetext{
${ }^{1}$ A Büntető Törvénykönyvről szóló 2012. évi C. törvény (továbbiakban: Btk.)
} 
tése), a költségvetést kárositó büncselekmények (különösen a költségvetési csalás), a pénzmosás, a korrupciós büncselekmények, a közbizalom elleni büncselekmények (különösen a közokirathamisítás és a hamis magánokirat felhasználása), valamint a tiltott adatszerzés és az információs rendszer elleni büncselekmények.

A fent felsorolt büncselekményi kategóriák közül a kutatás keretei közül kizárólag a költségvetést kárositó büncselekményeket elemeztük, hiszen ezek a deliktumok kifejezetten a társadalmi innováció pénzügyi alapjait érintik. Az össztársadalmi érdekeket szolgáló technológiák, megoldások, produktumok, illetve az ezek létrejöttéhez vezető folyamatok, eljárások ugyanis gyakran részesülnek különböző - hazai vagy nemzetközi forrásból származó - anyagi támogatásban. E tekintetben nemcsak a magyar költségvetés játszik fontos szerepet, hanem az Európai Unió is, amely - elsősorban a közös agrárpolitika és kohéziós politika terén - tevékenységek széles körét részesíti támogatásban. Az ezzel kapcsolatos kiadások finanszírozása az uniós költségvetésböl történik. A hazai és az uniós költségvetés sérelmére elkövetett deliktumok így közvetett módon a társadalmi innovációt is sérthetik, így a magyar és az uniós jogalkotónak is elemi érdeke fellépni az ilyen cselekményekkel szemben.

\section{Az Európai Unió pénzügyi érdekei, mint szupranacionális jogi tárgyak}

Az Európai Unió a tagállamoktól független, önálló költségvetéssel rendelkezik, amely összege évente 130-150 milliárd euró. E hatalmas összeg a bünelkövetők figyelmét is szükségszerúen magára vonta, így az uniós költségvetés sokféle, rendkívül változatos kriminális magatartás célpontjává vált. Ennek következtében az Unió hamar belátta, hogy a pénzügyi érdekeit hatékony védelemben kell részesítenie, amelyhez végső eszközként a büntetöjogot is igénybe kell vennie.

Az Európai Unió költségvetésének védelmét önmagában a tagállamok büntetőjoga nem tudja biztosítani, mivel az Unió pénzügyi érdekei ún. szupranacionális jogtárgynak, vagyis olyan védendő értéknek tekinthető, amely kifejezetten az Európai Unióhoz, mint szupranacionális entitáshoz kapcsolódik, és amely így túlnyúlik egy adott állam érdekein. ${ }^{2}$ Mivel a klasszikus nemzeti büntetőjog hatálya általában nem terjed ki más államok vagy nemzetközi szervezetek - pénzügyi és egyéb - érdekeinek védelmére, ezért szükségessé vált az egységes, uniós szintü védelem megteremtése. ${ }^{3}$

Az Európai Unió pénzügyi érdekei büntetöjogi védelmének megteremtéséhez ugyanakkor egy hoszszú és rögös út vezetett. Ez alapvetően arra a tényre vezethető vissza, hogy kezdetben az Európai Közösségek büntetőjogi hatáskörökkel nem rendelkeztek, ezáltal a szupranacionális költségvetést sértő cselekmények elleni fellépés is sokáig csak közigazgatási eszközökre korlátozódott.

Az első fontos mérföldkövet az 1992-ben aláírt Maastrichti Szerzödés jelentette, amely - az Európai Bíróság görög kukoricacsalás ügyében deklarált tételét ${ }^{4}$ átvéve - kimondta, hogy a tagállamok a Közösség pénzügyi érdekeit sértő csalások leküzdésére kötelesek megtenni ugyanazokat az intézkedéseket, mint amelyeket a saját pénzügyi érdekeiket sértő csalás leküzdésére tesznek. A tagállamok továbbá összehangolják a Közösség pénzügyi érdekeinek csalással szembeni védelmét célzó tevékenységüket, amely érdekében a Bizottság segítségével megszervezik a közigazgatásuk hatáskörrel rendelkező részlegei közötti szoros és rendszeres együttmüködést. ${ }^{5}$ A Maastrichti Szerződés rendelkezéseit az 1997-ben aláírt Amszterdami Szerzödés azzal egészítette ki, hogy jogalkotási felhatalmazást adott a Tanácsnak, hogy a Közösség pénzügyi érdekeit sértő csalások elleni küzdelem terén hozza meg a

\footnotetext{
${ }^{2}$ Karsai, K.: Mozaikkép a közösségi pénzügyi érdekek büntetőjogi védelméről, Európai Jog, 2002/5. pp. 19-20.

${ }^{3}$ Vö. Békés, Á.: Nemzetek feletti büntetőjog az Európai Unióban, HVG-ORAC Kiadó, Budapest, 2015. p. 61.

${ }^{4}$ 68/88. sz. Bizottság v. Görögország ügyben 1989. szeptember 21-én hozott ítélet [EBHT 1989., 2965.] 22-25.

${ }^{5}$ EK-Szerződés 209a. cikk
} 
szükséges intézkedéseket, amelyek biztosítják a tagállamokban a hathatós és azonos mértékủ védelmet. A jogalkotási felhatalmazásnak korlátja, hogy az elfogadott intézkedések nem érinthetik sem a nemzeti büntetöjog alkalmazását, sem a nemzeti igazságszolgáltatást ${ }^{6}$

A Maastrichti Szerződés ezenkívül a bel-és igazságügyi együttmüködést szabályozó III. pilléres együttmüködés keretében deklarálta, hogy a tagállamok az Unió célkitüzéseinek elérése céljából és az Európai Közösség hatásköreinek sérelme nélkül közös érdekü ügynek tekintik a nemzetközi méreteket öltő csalás elleni küzdelmet. ${ }^{7}$ Ezzel megnyílt az út, hogy az uniós jogalkotó - kizárólag a III. pilléres együttmüködés keretében, speciális jogforrásokban - büntetőjogi tárgyú intézkedéseket fogadjon el a pénzügyi érdekeket sértő cselekmények tárgyában. A Szerződés felhatalmazása alapján a tagállamok 1995-ben egy egyezményt fogadtak el az Európai Közösségek pénzügyi érdekeinek védelméröl ${ }^{8}$, amely meghatározta az Európai Közösségek pénzügyi érdekeit sértö csalás tényállását és kötelezte a tagállamokat, hogy a felsorolt megatartásokat nyilvánitsák büncselekménnyé és hatékony, arányos és visszatartó erejü szankciókkal büntessék. Az egyezményhez később három kiegészitö jegyzökönyvet is csatoltak, amelyek a pénzügyi érdekeket sértő egyéb büncselekmények (korrupció és pénzmosás), valamint a jogi személyek szankcionálásáról rendelkeztek. ${ }^{9}$

A PIF egyezmény és jegyzőkönyvei jelentős állomást jelentettek az Unió pénzügyi érdekeit sértő cselekmények elleni küzdelemben, mivel ezek voltak az első olyan jogi aktusok, amelyek kifejezetten az uniós költségvetést sértő cselekmények büntetőjogi szankcionálását írták elő. Hátrányként értékelhetjük, hogy a tagállami ratifikációk elhúzódása miatt az egyezmény és a kiegészítő jegyzőkönyvek csak hosszabb idő elteltével léptek hatályba és a tagállamok többsége nem vagy nem megfelelöen ültette át az egyezmény és a kiegészítő jegyzőkönyvek rendelkezéseit a nemzeti jogába.

\section{Az Európai Unió pénzügyi érdekeinek védelme a Lisszaboni Szerződésben}

Az Európai Unió pénzügyi érdekeinek védelme - és az uniós büntetőjogi integráció - történetében a továbblépés lehetőségét a 2007-ben aláírt Lisszaboni Szerzödés teremtette meg. A Szerződés megszüntette az Unió pilléres rendszerét, amely hatására a korábbi III. pillér megszünt és az uniós büntetöjogi együttmüködés is szupranacionális hatáskörbe került. A Lisszaboni Szerződés széleskörü jogalkotási hatásköröket ruházott az uniós jogalkotóra, amelyeket négy csoportra lehet osztani.

1. Az EUMSz. 83. cikk (1) bekezdésében szabályozott jogharmonizációs hatáskör értelmében az Európai Parlament és a Tanács irányelvekben szabályozási minimumokat állapíthat meg a büncselekményi tényállások és a büntetési tételek meghatározására vonatkozóan az olyan különösen súlyos büncselekmények esetében, amelyek jellegüknél vagy hatásuknál fogva több államra kiterjedő vonatkozásúak, illetve amelyek esetében különösen szükséges, hogy az ellenük folytatott küzdelem közös alapokon nyugodjék. A Szerződés tíz ilyen uniós dimenzióval rendelkezö delik-

\footnotetext{
${ }^{6}$ EK-Szerződés 280. cikk (4) bekezdés

${ }^{7}$ EU-Szerződés K.1. cikk 5. pont

8 A Tanács jogi aktusa (1995. július 26.) az Európai Közösségek pénzügyi érdekeinek védelméröl szóló egyezmény létrehozásáról [HL C 316., 1995.11.27., 48-57.] (továbbiakban: PIF egyezmény)

9 A Tanács jogi aktusa (1996. szeptember 27.) az Európai Közösségek pénzügyi érdekeinek védelméről szóló egyezményhez csatolt jegyzőkönyv létrehozásáról [HL C 313., 1996.10.23., 1-11.], a Tanács jogi aktusa (1996. november 29.) az Európai Unióról szóló szerződés K.3 cikke alapján, az Európai Közösségek pénzügyi érdekeinek védelméről szóló egyezménynek az Európai Közösségek Bírósága által, előzetes döntéshozatal révén történő értelmezéséről szóló jegyzőkönyv létrehozásáról [HL C 151., 1997.05.20., 1-14.], a Tanács jogi aktusa (1997. június 19.) az Európai Közösségek pénzügyi érdekeinek védelméröl szóló egyezmény második jegyzőkönyve szövegének kidolgozásáról [HL C 221., 1997.07.19., 11-22.]
} 
tumot sorol fel (terrorizmus, emberkereskedelem és a nők és gyermekek szexuális kizsákmányolása, tiltott kábítószer-kereskedelem, tiltott fegyverkereskedelem, pénzmosás, korrupció, pénz és egyéb fizetőeszközök hamisítása, számítógépes bünözés, szervezett bünözés), a Tanács ugyanakkor a bünözés alakulásának függvényében egyhangú határozatban egyéb büncselekményi területeket is a szabályozás hatálya alá vonhat.

2. Az EUMSz. 83. cikk (2) bekezdése szerinti járulékos harmonizációs hatáskör abban az esetben tesz lehetővé büncselekményi tényállásokra és a büntetési tételekre vonatkozó szabályozási minimumok elfogadását, amennyiben valamely harmonizációs intézkedések hatálya alá tartozó területen az Unió politikájának eredményes végrehajtásához elengedhetetlen a tagállamok büntetöügyekre vonatkozó törvényi, rendeleti és közigazgatási rendelkezéseinek közelítése.

3. Az EUMSz. 325. cikke kifejezetten az Európai Unió pénzügyi érdekeinek védelmére fókuszál és arra kötelezi az Uniót és a tagállamokat, hogy elrettentő hatású és hatékony intézkedésekkel küzdjenek a csalás és a pénzügyi érdekeket sértő jogellenes tevékenységek ellen. Ennek érdekében az uniós jogalkotó meghozhatja a csalások megelőzése és az azok elleni küzdelem terén a szükséges intézkedéseket azzal a céllal, hogy hathatós és azonos mértékü védelmet nyújtsanak a tagállamokban, valamint az Unió intézményeiben, szerveiben és hivatalaiban.

4. Az EUMSz. 86. cikke lehetővé teszi, hogy az Unió pénzügyi érdekeit sértő büncselekmények üldözésére a Tanács az Eurojustból Európai Ügyészséget hozzon létre. Az Európai Ügyészség hatáskörrel rendelkezik az Unió pénzügyi érdekeit sértő büncselekmények tetteseinek és részeseinek felkutatására, velük szemben a nyomozás lefolytatására és bíróság elé állításukra. Az Európai Ügyészség hatásköre ugyanakkor egyhangú tanácsi határozattal más, több államra kiterjedő vonatkozású súlyos büncselekményre is kiterjeszthető.

A Lisszaboni Szerződés büntetőjogi hatáskörei alapján intenzív jogalkotási folyamat indult meg, amely eredményeképpen két jogi aktust fogadtak el: az Unió pénzügyi érdekeit érintö csalás ellen büntetőjogi eszközökkel folytatott küzdelemröl szóló irányelvet ${ }^{10}$, és az Európai Ügyészségröl szóló rendeletet. ${ }^{11}$ Míg az ún. PIF irányelv a csalás elleni küzdelem anyagi büntetőjogi kereteit rögzíti, addig az EPPO rendelet a pénzügyi érdekek büntetőjogi védelmének eljárásjogi oldalát szabályozza.

\subsection{A PIF irányelv}

A PIF irányelv célja, hogy az Unió pénzügyi érdekeit érintő csalás és egyéb jogellenes tevékenységek elleni küzdelem terén a büncselekmények és a büntetöjogi szankciók fogalmának meghatározására vonatkozó minimumszabályokat állapítson meg, azzal a céllal, hogy erösitse az Unió pénzügyi érdekeit érintö büncselekményekkel szembeni védelmet. ${ }^{12}$

Ennek érdekében az irányelv meghatározza azokat a büncselekményi tényállásokat, amelyeket a tagállamoknak büncselekménnyé kell nyilvánitaniuk. Az Unió pénzügyi érdekeit érintö csalás fogalmát érintően az irányelv a közbeszerzésekhez kapcsolódó és a nem közbeszerzésekhez kapcsolódó kiadások, illetve a HÉA-alapú saját forrásból származó és az azon kívüli bevételek tekintetében elkövetett jogsértő magatartások között tesz különbséget. Az irányelv az uniós csalás mellett három további

\footnotetext{
${ }^{10}$ Az Európai Parlament és a Tanács (EU) 2017/1371 irányelve (2017. július 5.) az Unió pénzügyi érdekeit érintő csalás ellen büntetőjogi eszközökkel folytatott küzdelemről [HL L 198., 2017.07.28., 29-41.] (továbbiakban: PIF irányelv)

${ }^{11}$ A Tanács (EU) 2017/1939 rendelete (2017. október 12.) az Európai Ügyészség létrehozására vonatkozó megerősített együttmüködés bevezetéséről [HL L 283., 2017.10.31., 1-71.] (továbbiakban: EPPO rendelet)

${ }^{12}$ PIF irányelv 1. cikk
} 
olyan büncselekmény tényállását - pénzmosás, aktív és passzív hivatali vesztegetés, hütlen kezelés - is rögzíti, amelyek szintén sérthetik vagy veszélyeztetik az Unió pénzügyi érdekeit. ${ }^{13}$

Az irányelv kötelezi a tagállamokat arra, hogy a felsorolt cselekményeket nyilvánitsák büncselekménnyé, és hatékony, arányos és visszatartó erejü szankciókkal sújtsák. Különösen súlyos esetben, amikor a büncselekménnyel elért előny vagy az azzal járó kár a 100.000 eurót meghaladja, a tagállamoknak maximális büntetésként legalább 4 éves szabadságvesztést kell elöírniuk. 10.000 eurónál kisebb kárt okozó vagy előnyt eredményező, csekélyebb súlyú cselekmények esetén ugyanakkor a tagállamok szabadon eldönthetik, hogy büntetöjogi vagy más jogágba tartozó (például polgári jogi, adminisztrativ) szankciókat írjanak elö. ${ }^{14}$ A természetes személyek mellett a PIF irányelv kötelezi a tagállamokat a jogi személyek felelösségre vonhatóságának megteremtésére is. ${ }^{15}$

\subsection{Az EPPO rendelet}

Az Európai Ügyészség egy uniós szintü nyomozóhatóság, amely az Unió pénzügyi érdekeit sértő bűncselekmények elkövetőivel és azok büntársaival szemben nyomozási és vádemelési hatáskörökkel rendelkezik. Ebben a vonatkozásban az Ügyészség nyomozásokat folytat, eljárási cselekményeket végez, valamint ellátja az ügyészi feladatokat a tagállamok illetékes bíróságain az egyes ügyek jogerős lezárásáig. ${ }^{16}$ Az Európai Ügyészség jogi személyiséggel rendelkezö, decentralizált felépitésü, egységes hivatalként müködö, oszthatatlan uniós szerv. ${ }^{17}$

Az Európai Ügyészség hatáskörébe tartoznak egyrészt a - nemzeti jogba átültetett - PIF irányelv által szabályozott, az Unió pénzügyi érdekeit sértö büncselekmények (uniós csalás, pénzmosás, aktív és passzív vesztegetés, hütlen kezelés); másrészt a bünszervezetben való részvétellel kapcsolatos deliktumok, amennyiben a bünszervezet által folytatott büntetendő tevékenység az Unió pénzügyi érdekeit sértő valamely büncselekmény elkövetésére irányul; harmadrészt pedig bármely olyan büncselekmény, amely elválaszthatatlanul kapcsolódik a pénzügyi érdekeket sértő büntetendő cselekményekhez. ${ }^{18}$ Az Európai Ügyészség a hatáskörébe tartozó büncselekmény elkövetése esetén hivatalból, az officialitás elve alapján köteles eljárni. Az EPPO rendelet részletesen szabályozza az eljárás megindítására, a nyomozás lefolytatására és lezárására, a vádemelésre, a bizonyítékok felhasználására, valamint a bírósági felülvizsgálatra vonatkozó szabályokat. ${ }^{19}$

Fontos megemlíteni ugyanakkor, hogy az Európai Ügyészség ún. megerösitett együttmüködés keretében jött létre, amelynek jelenleg 22 tagállam tagja. Az Ügyészség működésében jelenleg Dánia, Írország, Lengyelország, Magyarország és Svédország nem vesz részt.

\section{Az Európai Unió pénzügyi érdekeinek védelme a magyar büntetőjogban}

Az Európai Unió pénzügyi érdekeinek védelmét valamennyi uniós tagállamnak, így hazánknak is biztosítania kell. Magyarországnak az Európai Közösség pénzügyi érdekei büntetőjogi védelmének feltételeit már az uniós csatlakozás elött meg kellett teremtenie. Ennek biztosítása érdekében a 2002.

\footnotetext{
${ }^{13}$ PIF irányelv 3-4. cikk

${ }^{14}$ PIF irányelv 7-8. cikk

15 PIF irányelv 6, 9. cikk

${ }^{16}$ EPPO rendelet 4. cikk

${ }^{17}$ EPPO rendelet 3. cikk (2) bekezdés és 8. cikk (1) bekezdés

${ }^{18}$ EPPO rendelet 22. cikk

${ }^{19}$ EPPO rendelet 24-42. cikk
} 
április 1-én hatályba lépett 2001. évi CXXI. törvény az 1978. évi Btk. ${ }^{20} 314$. §-ába illesztette az Európai Közösség pénzügyi érdekeinek megsértése elnevezésü büncselekményt.

A tényállást a 2011. évi LXIII. törvény 2012. január 1-jével hatályon kívül helyezte és a büncselekményt a korábbi Btk. 310. §-a által szabályozott költségvetési csalás tényállása alá vonta. A tényállást a 2013. július 1-jén hatályba lépett Btk. is átvette. A hatályos Btk. a XXXIX. fejezetben szabályozza a költségvetést kárositó büncselekményeket. E fejezet négy tényállást tartalmaz: a társadalombiztositási, szociális vagy más jóléti juttatással visszaélést (395. §), a költségvetési csalást (396. §), a költségvetési csaláshoz kapcsolódó felügyeleti vagy ellenörzési kötelezettség elmulasztását (397. §) és a jövedékkel visszaélés elösegitését (398. §). A hazai és az uniós költségvetés védelmét így a hatályos szabályozás értelmében elsődlegesen a költségvetési csalás tényállása biztosítja.

A költésvetési csalás tényállása megalkotásával a jogalkotó a költségvetést sértő valamennyi bűncselekményt egy cím alá vonta össze. A törvényhozó a tényállás megalkotásánál azt a célt tüzte ki, hogy magát a költségvetést állitsa a védelem fókuszába, és az annak sérelmét jelentő elkövetési magatartásokat a lehető legabsztraktabb módon fogalmazza meg, hogy így a különböző „kiskapuk” és viszszaélési lehetőségek kiiktatásával fokozza a védelem hatékonyságát. A Btk. 396. §-a által szabályozott büncselekmény jogi tárgya így közvetve a költségvetések prudens müködéséhez füzödö társadalmi érdek, közvetlenül pedig maguk a költségvetések lettek. ${ }^{21} \mathrm{~A}$ tényállás három alapesetben szabályozza a költségvetést károsító cselekményeket: eszerint különbséget tehetünk a szükebb értelemben vett költségvetési csalás, a jövedéki termékre elkövetett költségvetési csalás, valamint a költségvetésböl származó pénzeszközökkel kapcsolatos elszámolási, számadási és tájékoztatási kötelezettség megszegése (adminisztratív költségvetési csalás) között. ${ }^{22}$

A magyar büntetőjogi szabályozást vizsgálva megállapítható, hogy a magyar jogalkotó teljes egészében átültette a PIF irányelv vonatkozó rendelkezéseit, a költségvetési csalás elkövetési magatartásai - a magyar büntetőjogi dogmatikával való összeegyeztethetőséghez szükségszerü kisebb módosításokkal - megfeleltethetők a PIF irányelvben szereplő magatartásoknak. Az elkövetési magatartásokat és a szankciókat tekintve a magyar büntetőjog az uniós követelményekhez képest szigorúbban szankcionálja az Európai Unió pénzügyi érdekeinek megsértését.

\section{Záró gondolatok}

Összegzésképpen megállapíthatjuk, hogy az Európai Unió folyamatosan törekszik a pénzügyi érdekei büntetőjogi védelme hatékonyságának növelésére. Ebben a küzdelemben az uniós jogalkotó a Lisszaboni Szerződéssel megerősített büntetőjogi jogalkotási hatásköröket kapott, amely alapján 2017-ben két fontos uniós jogi aktust fogadott el. Álláspontunk szerint mind a PIF irányelv, mind pedig az EPPO rendelet nagyon fontos és hatékony eszköz lehet az Unió pénzügyi érdekeinek védelme terén.

Az Európai Unió pénzügyi érdekeinek védelmét a magyar jogalkotó is biztosítja, eleget téve az uniós jogból eredö jogharmonizációs és implementációs kötelezettségének. A magyar Büntető Törvénykönyvben szereplő költségvetési csalás tényállása teljes egészében összhangban áll a PIF irányelvvel, sőt - az irányelv minimumharmonizációs szabályozásával összhangban - gyakran még szigorúbb szabályokat is tartalmaz, mint az uniós jogforrás. Ugyanakkor Magyarország nem vesz részt az

\footnotetext{
${ }^{20}$ 1978. évi IV. törvény a Büntető Törvénykönyvről (továbbiakban: korábbi Btk.)

${ }^{21}$ A 2011. évi LXIII. törvény és a Btk. miniszteri indokolása

${ }^{22}$ Bővebben lásd: Jacsó, J.: A költségvetési csalás, In: Barabás, T., Hollán, M. (szerk.): A negyedik magyar büntetőkódex - régi és újabb vitakérdései MTA Társadalomtudományi Kutatóintézet, Országos Kriminológiai Intézet, Budapest, 2017. pp. 267-293.
} 
Európai Ügyészség működésében, így az Unió pénzügyi érdekeinek védelmét a magyar jogalkalmazó szerveknek kell biztosítaniuk.

\section{Köszönetnyilvánítás}

A cikkben ismertetett kutató munka az EFOP-3.6.1-16-2016-00011 jelü „Fiatalodó és Megújuló Egyetem - Innovatív Tudásváros - a Miskolci Egyetem intelligens szakosodást szolgáló intézményi fejlesztése" projekt részeként - a Széchenyi 2020 keretében - az Európai Unió támogatásával, az Európai Szociális Alap társfinanszírozásával valósul meg.

\section{Irodalom}

[1] Békés, Á.: Nemzetek feletti büntetőjog az Európai Unióban, HVG-ORAC Kiadó, Budapest, 2015.

[2] Jacsó, J.: A költségvetési csalás, In: Barabás, T., Hollán, M. (szerk.): A negyedik magyar büntetőkódex - régi és újabb vitakérdései MTA Társadalomtudományi Kutatóintézet, Országos Kriminológiai Intézet, Budapest, 2017.

[3] Karsai, K.: Mozaikkép a közösségi pénzügyi érdekek büntetőjogi védelméröl, Európai Jog, $2002 / 5$. 